\title{
A novel mutation in the human thyroid peroxidase gene resulting in a total iodide organification defect
}

\author{
T Kotani, K Umeki, I Yamamoto, H Maesaka ${ }^{1}$, K Tachibana ${ }^{1}$ and \\ S Ohtaki
}

Department of Laboratory Medicine, Miyazaki Medical College, Kiyotake, Miyazaki 889-1692, Japan

${ }^{1}$ Department of Pediatrics, Kanagawa Children's Medical Center, Minami-ku Mutsukawa 2, Yokohama 232-8555, Japan

(Requests for offprints should be addressed to S Ohtaki)

\begin{abstract}
In this study we describe a novel mutation of the thyroid peroxidase (TPO) gene that resulted in a total iodide organification defect. TPO activity and thyroxine formation in thyroglobulin in the thyroid gland of the patient were below the limits of detection. However, TPO mRNA was detectable at a similar size and concentration as compared with normal thyroid tissues when measured by Northern blot analysis. Sequence analysis of the TPO gene showed the presence of two mutations, a missense mutation in exon 7 and $\mathrm{C}$ insertion in exon 14. These mutations were heterozygous and located in different alleles. The latter mutation has already been reported as
\end{abstract}

one of the mutations of the TPO gene resulting in total iodide organification defect. The former mutation was further analysed by mRNA transfection studies in which mutated mRNA was transfected to $\mathrm{CHO}-\mathrm{K} 1$ cells by electroporation. The results of transfection studies showed that the cells transfected with mutated mRNA expressed similar size TPO molecules to those of cells transfected with wild-type mRNA but that they lacked TPO activity. The two mutations of the TPO gene resulting in the total iodide organification defect in the patient cosegregated from her parents.

Journal of Endocrinology (1999) 160, 267-273

\section{Introduction}

Thyroid peroxidase (TPO) is a key enzyme in the synthesis of thyroid hormones. It catalyzes both iodination and coupling of iodotyrosine residues in thyroglobulin (Tg) (Taurog 1986). The human TPO gene is located on chromosome 2p25 (Endo et al. 1995), covers approximately 150 kilobases $(\mathrm{kb})$ of DNA, and is divided into 17 exons (Kimura et al. 1989). Full-length TPO mRNA is $3 \mathrm{~kb}$ (Kimura et al. 1987, Libert et al. 1987, Seto et al. 1987).

Most cases of congenital hypothyroidism result from dysembryogenesis of the thyroid gland. Hereditary inborn errors in thyroid hormone synthesis are found in 10-20\% of these patients, and are mostly caused by defects in the synthesis or iodination of Tg (Bikker et al. 1994). The most prevalent cause of inherited defects in thyroid hormone synthesis is believed to be due to TPO deficiency (Mangklabruks et al. 1991). Recent studies have found seven mutations in the human TPO gene that cause total iodide organification defect (TIOD): $20 \mathrm{bp}$ duplication at position 141 in exon 2 (Bikker et al. 1994), GGCC duplication at position 1277 in exon 8 (Abramowicz et al. 1992), T1447G missense mutation in exon 9 (Bikker et al. 1995), C1708T missense mutation in exon 10 (Bikker et al. 1996), G1858A missense mutation in exon 10 (Bikker et al. 1996), G2485A missense mutation in exon 14 (Bikker et al. 1995) and C insertion at position 2505-2511 in exon 14 (Bikker et al. 1995). In this paper we describe a novel mutation causing TPO deficiency. This mutation is a missense mutation in exon 7 .

\section{Subjects and Methods}

\section{Patient}

The patient was born after a 41-week gestation in 1977, when neonatal screening for congenital hypothyroidism had not been introduced in Japan. Body weight at birth was $4150 \mathrm{~g}$. At the age of 3.5 months, congenital hypothyroidism was diagnosed on the basis of clinical symptoms suggesting hypothyroidism and laboratory serum data (thyoid-stimulating hormone (TSH), $340 \mu \mathrm{U} / \mathrm{ml}$ (normal range, $0 \cdot 5-5 \cdot 0 \mu \mathrm{U} / \mathrm{ml})$; total thyroxine $\left(\mathrm{T}_{4}\right),<6 \cdot 4 \mathrm{nmol} / 1$ (normal range, $59 \cdot 2-162 \cdot 2 \mathrm{nmol} / \mathrm{l}$ ); total tri-iodothyronine $\left(\mathrm{T}_{3}\right), 0 \cdot 3 \mathrm{nmol} / 1$ (normal range, $1 \cdot 2-3 \cdot 4 \mathrm{nmol} / \mathrm{l}$ ); triosorb test, $21 \cdot 9 \%$ (normal range, $25-37 \%)$ ). Goitre was palpable but not visible.

${ }^{131}$ I-Thyroid uptake was $15 \%$ at $24 \mathrm{~h}$ (normal range, 10-40\%). The perchlorate discharge test was positive 
(52.9\%) $60 \mathrm{~min}$ after oral administration of sodium perchlorate at a dose of $1 \mathrm{~g}$, when ${ }^{131}$ I-thyroid uptake was $10 \%$ at $5 \mathrm{~h}$. Serum TSH exhibited an excessively high and delayed response to thyrotrophin (TRH) stimulation. TSH was $240 \mu \mathrm{U} / \mathrm{ml}$ before, $320 \mu \mathrm{U} / \mathrm{ml}$ at $30 \mathrm{~min}, 255 \mu \mathrm{U} / \mathrm{ml}$ at $60 \mathrm{~min}, 320 \mu \mathrm{U} / \mathrm{ml}$ at $90 \mathrm{~min}$ and $195 \mu \mathrm{U} / \mathrm{ml}$ at $120 \mathrm{~min}$ after the intramuscular injection of TRH at a dose of $5 \mu \mathrm{g} / \mathrm{kg}$. The patient was treated with thyroid hormone immediately after admission. At 1.7 years of age, the medication was interrupted transiently and these tests were repeated. ${ }^{131}$ I-Thyroid uptake was $26 \%$ at $3 \mathrm{~h}$ and $8 \%$ at $24 \mathrm{~h}$. The perchlorate discharge test was positive (82.3\%) $60 \mathrm{~min}$ after oral administration of sodium perchlorate at a dose of $2 \mathrm{~g}$, when ${ }^{131}$ I-thyroid uptake was $31 \%$ at $4 \mathrm{~h}$. From these results, the patient was diagnosed as TIOD.

During thyroid hormone replacement therapy, small nodular goitres developed in the right lobe at the age of 14 years. The serum $\mathrm{Tg}$ level was very high $(1050 \mathrm{ng} / \mathrm{ml})$, but anti-Tg autoantibody was not detected. At the age of 18 years, the nodular goitres increased in number and grew. The maximum one was $3 \times 4 \mathrm{~cm}$ in diameter. Right lobectomy was performed. The adenoma and surrounding thyroid tissues were frozen separately in liquid nitrogen and stored at $-70{ }^{\circ} \mathrm{C}$. The pathological finding was follicular adenoma (embryonal type). Preoperative values at the age of 18 years were as follows: TSH, $5.5 \mu \mathrm{U} / \mathrm{ml}$; total $\mathrm{T}_{4}, 97.8 \mathrm{nmol} / 1$; total $\mathrm{T}_{3}, 1.7 \mathrm{nmol} / \mathrm{l}$; $\mathrm{Tg}, 3000 \mathrm{ng} / \mathrm{ml}$.

The parents were not consanguineous and had no common ancestors. They had normal thyroid function. Informed consent for these examinations was obtained from the parents because of the patient's low IQ.

\section{Microsomal and supernatant fractions of thyroid tissue}

The procedure used to prepare microsomal and supernatant fractions of thyroid tissue has been described previously (Nakagawa et al. 1985b). The protein concentration of both fractions was determined by the Bradford method (Bradford 1976) using bovine serum albumin as a standard.

\section{SDS-polyacrylamide gel electrophoresis (PAGE)}

The procedure for SDS-PAGE was carried out as described by Laemmli (1970). The supernatant of thyroid tissue $(20 \mu \mathrm{g})$ was treated with 5\% 2-mercaptoethanol and subjected to electrophoresis. Protein bands were visualized by staining with Coomassie brilliant blue R-250.

\section{Western blot analysis}

The Western blot procedure has been described previously (Nakagawa et al. 1985a). The microsomal fraction of thyroid tissue $(20 \mu \mathrm{g})$ was electrophoresed on $7 \cdot 5 \%$
SDS-polyacrylamide gel and transferred to Immobilon-P (Millipore Corporation, Bedford, MA, USA). The membrane was incubated with polyclonal rabbit anti-human TPO antibody (Kotani et al. 1986a) and then reacted with goat anti-rabbit $\operatorname{IgG}$ antibody conjugated with alkaline phosphatase (Promega Corporation, Madison, WI, USA).

\section{Immunohistochemical staining}

Frozen tissue sections ( $4 \mu \mathrm{m}$ thick) were stained by an immunoperoxidase streptoavidin-biotin complex method using a Histofine SAB-PO(M) kit (Nichirei, Tokyo, Japan). All staining steps were carried out according to the manufacturer's instructions. Mouse monoclonal antibody 16.3.2 (Kotani et al. 1986b) was used to stain $\mathrm{T}_{4}$.

\section{Guaiacol oxidation assay}

TPO activity was determined as described previously (Nakagawa et al. 1981). One unit of enzyme oxidized $1 \mu \mathrm{mol}$ guaiacol/min in $0 \cdot 1 \mathrm{M}$ phosphate buffer $(\mathrm{pH} 7 \cdot 5)$.

\section{Northern blot analysis}

Total cellular RNA was isolated from the adenoma and surrounding thyroid tissues (Kimura et al. 1987, Sambrook et al. 1989). RNA $(10 \mu \mathrm{g})$ was electrophoresed through formaldehyde agarose gel, transferred to a Zeta-probe membrane (Bio-Rad, Richmond, NJ, USA), and baked at $80{ }^{\circ} \mathrm{C}$ for $2 \mathrm{~h}$. The membrane was prehybridized for $3 \mathrm{~h}$, hybridized overnight, and washed according to the manufacturer's instructions. The membrane was exposed to Kodak X-OMAT AR X-ray film with intensifying screens at $-80{ }^{\circ} \mathrm{C}$. The cDNA probes, a $2 \cdot 4 \mathrm{~kb}$ EcoRI/ SacI fragment of human TPO cDNA (Kimura et al. 1987) and a $0.4 \mathrm{~kb}$ EcoRI fragment of human $\beta$-actin cDNA (kindly provided by Dr S Tohda, Tokyo Medical and Dental University, Tokyo, Japan), were labelled with $\left[\alpha-{ }^{32} \mathrm{P}\right] \mathrm{dCTP}$ using a Takara Random Primer DNA Labelling Kit (Takara Shuzo, Otsu, Japan).

\section{Polymerase chain reaction (PCR)}

cDNA was synthesized for reverse transcriptase (RT)PCR. The reaction mixture $(100 \mu \mathrm{l})$ contained $5 \mu \mathrm{g}$ total cellular RNA in $10 \mathrm{mM}$ Tris- $\mathrm{HCl}(\mathrm{pH} 8 \cdot 3), 1.5 \mathrm{mM}$ $\mathrm{MgCl}_{2}, 50 \mathrm{mM} \mathrm{KCl}, 1 \mathrm{mM}$ of each dNTP, $600 \mathrm{pmol}$ random primer (6 mer; Takara Shuzo), $55 \mathrm{U}$ RNase inhibitor (Takara Shuzo), and $1000 \mathrm{U}$ Moloney murine leukemia virus RT (Gibco BRL, Gaithersburg, MD, USA). The mixture was incubated at $25^{\circ} \mathrm{C}$ for $10 \mathrm{~min}$, then at $42{ }^{\circ} \mathrm{C}$ for $60 \mathrm{~min}$ and heated at $95^{\circ} \mathrm{C}$ for $5 \mathrm{~min}$. Using the synthesized cDNA, a reaction mixture $(20 \mu \mathrm{l})$ for PCR was prepared containing $1 \times \mathrm{Ex}$ Taq buffer (Takara Shuzo), 0.5 U Ex Taq (Takara Shuzo), and $4 \mu \mathrm{l}$ cDNA. The PCR reaction was performed in a Takara 
Table 1 PCR primers used in this study

\begin{tabular}{|c|c|c|c|}
\hline & Primer & Sequence & PCR product \\
\hline \multicolumn{4}{|c|}{ Amplifying region* } \\
\hline A $24-568$ & F0024 & 5'-CAGAAGAGTTACAGCCGTGA-3' & \multirow{2}{*}{$545 \mathrm{bp}$} \\
\hline of cDNA & R0549 & 5'-TGTTGCAAGCTCCTGTGATG-3' & \\
\hline В 519-1058 & F0519 & 5'-AAACACTTGCCTGGCGAACA-3' & \multirow{2}{*}{540 bp } \\
\hline of cDNA & R1039 & 5'-AACGAGGTCAACCCGTTCAT-3' & \\
\hline C 999-1547 & F0999 & 5'-GCTCTITGGGAACCTGTCCA-3' & \multirow{2}{*}{$549 \mathrm{bp}$} \\
\hline of cDNA & R1528 & 5'-GAGAACACGTTGGACACAGT-3' & \\
\hline D $1497-2073$ & F1497 & 5'-CTATGAAGGCTATGACTCCA-3' & \multirow{2}{*}{577 bp } \\
\hline of cDNA & R2054 & $5^{\prime}$-CATCTGCTTCCCAATGAGAC-3' & \\
\hline E $1975-2546$ & F1975 & 5'-CCTGACAACATCGATGTCTG-3' & \multirow{2}{*}{572 bp } \\
\hline of cDNA & R2527 & 5'-CCTTTGGTGTTCTGCACCT-3' & \\
\hline \multirow{4}{*}{ F $\begin{array}{l}2471-3045 \\
\text { of cDNA } \\
\text { Exon } 1\end{array}$} & F2471 & $5^{\prime}$-GCAAAGATGTGAACGAGTGT-3' & \multirow{2}{*}{$575 \mathrm{bp}$} \\
\hline & R3026 & 5'-CCATGCCTGAGAGTAACTAC-3' & \\
\hline & $\mathrm{E} \times 1 \mathrm{~F}$ & 5'-GCAAGTGTCACAAGTCTGGA-3' & \multirow{2}{*}{$516 \mathrm{bp}$} \\
\hline & $E \times 1 R$ & 5'-ACTCATCAGTCAGTCAGTCA-3' & \\
\hline \multirow[t]{2}{*}{ Exon 7} & $E \times 7 F$ & 5'-AGGTCATCTTTCTGCTACCA-3' & \multirow{2}{*}{389 bp } \\
\hline & $E \times 7 R$ & 5'-CTACCCCTGGGAATAGGACA-3' & \\
\hline \multirow[t]{2}{*}{ Exon 14} & $\mathrm{E} \times 14 \mathrm{~F}$ & 5'-GACCTCCCCAGAGAGAAGCA-3' & \multirow{2}{*}{327 bp } \\
\hline & $E \times 14 R$ & 5'-GATGGTGATTGACAGTTGCC-3' & \\
\hline
\end{tabular}

*Numbering is according to Kimura et al. (1989). F, forward; R, reverse; E, exon.

PCR Thermal Cycler MP (Takara Shuzo) for 30 cycles, each consisting of denaturation at $98^{\circ} \mathrm{C}$ for $20 \mathrm{~s}$, annealing at $55^{\circ} \mathrm{C}$ for $30 \mathrm{~s}$, and extension at $72{ }^{\circ} \mathrm{C}$ for $1 \mathrm{~min}$.

For genomic DNA PCR, $200 \mathrm{ng}$ genomic DNA prepared from surrounding thyroid tissue or peripheral blood mononuclear cells was used in the reaction mixture instead of $4 \mu \mathrm{l}$ cDNA. The PCR reaction was carried out using the same procedure as described for RT-PCR. Primer sets used for PCR amplification are summarized in Table 1.

\section{Sequencing}

PCR product was directly ligated to the pGEM-T Easy Vector System (Promega Corporation) according to the manufacturer's instructions. Nucleotide sequencing was carried out with an ABI PRISM Dye Primer Cycle Sequencing FS Core Kit (Perkin Elmer, Norwalk, CT, USA) and an ABI 373A automatic sequencer (Perkin Elmer). At least five independent clones of the PCR product were sequenced.

\section{Preparation of $m R N A$ and transfection}

PCR product with G808A mutation (primers F0519 and R2527) ligated to the pGEM-T vector and hTPO-1 cDNA inserted to the EcoRI site of the pUC19 vector were cut with BbeI and MluI. Liberated BbeI/MluI fragment from the PCR product was ligated to the BbeI and MluI sites of the hTPO-1 cDNA (G808A cDNA). G808A and hTPO-1 cDNAs cut out from the pUC19 vectors at the sites of EcoRI were blunt-ended and then ligated to the SmaI site of the pSFV-1 vectors (Gibco
BRL, Rockville, MD, USA). Direction of the inserted cDNAs was confirmed by restriction enzyme sites. The pSFV-1 vectors containing G808A and hTPO-1 cDNAs were linearized with SpeI. RNA synthesis was performed according to the manufacturer's instructions using an mMESSAGE mMACHINE Kit (Ambion, Inc., Austin, TX, USA).

CHO-K1 cells were maintained in $\alpha$-MEM (Nissui Pharmaceutical Co., Tokyo, Japan) supplemented with $10 \%$ fetal calf serum (FCS) and kanamycin $(200 \mathrm{mg} / \mathrm{l})$. Seven million cells and $30 \mu \mathrm{g}$ mRNA were mixed in a $4 \mathrm{~mm}$ cuvette and electroshocked. Electroporation was performed at $260 \mathrm{~V}, 1500$ microfarads and $0 \cdot 48 \mu \mathrm{s}$. Thereafter, the cells were plated in a $10 \mathrm{~cm}$ dish and cultured for 24 or $34 \mathrm{~h}$ in the presence of $1 \mu \mathrm{g} / \mathrm{ml}$ hematin.

The cells detached with mild trypsin treatment were washed three times with cold phosphate-buffered saline (PBS) and suspended in cold sucrose solution $(10 \mathrm{mM}$ $\mathrm{K}_{2} \mathrm{HPO}_{4}$, $\mathrm{pH} 7 \cdot 4$, and $0 \cdot 86 \%$ sucrose) at $1 \times 10^{7}$ cells $/ \mathrm{ml}$. After brief sonication, a microsomal fraction was prepared and dissolved in $20 \mathrm{mM}$ Tris buffer $(\mathrm{pH} 7 \cdot 5)$. The protein concentration was $5-7 \mathrm{mg} / \mathrm{ml}$.

\section{Results and Discussion}

\section{TPO lacking its activity}

In both thyroid tissues of the patient, adenoma and surrounding thyroid tissue, Tg was analysed by SDSPAGE and immunohistochemistry. The results suggested that $\mathrm{Tg}$ was normally synthesized but $\mathrm{T}_{4}$ formation in the $\mathrm{Tg}$ molecule was impaired. 


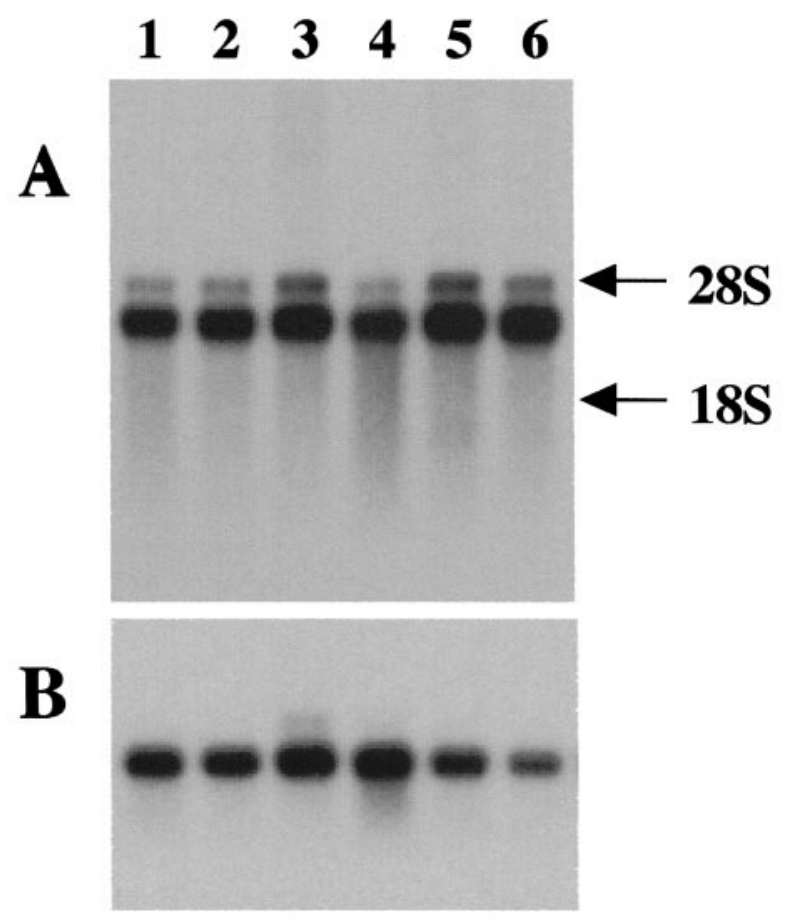

Figure 1 Northern blot analysis. (A) $10 \mu \mathrm{g}$ total cellular RNA from surrounding thyroid tissue (lane 1), adenoma (lane 2), normal thyroid tissues (lanes 3 and 4 ) and Graves' disease thyroid tissues (lanes 5 and 6) were hybridized to a $2 \cdot 4 \mathrm{~kb}$ TPO cDNA probe. (B) The same filter as used in (A) was rehybridized to a $0.4 \mathrm{~kb}$ human $\beta$-actin cDNA probe.

TPO enzyme activity was undetectable in the microsomal fractions of the patient's thyroid tissues (normal values, $0 \cdot 15-0 \cdot 24$ units $/ \mathrm{mg}$ microsomal protein). The supernatants also showed no activity. Western blot analysis using polyclonal rabbit anti-human TPO antibody revealed that the patient's thyroid tissues contained TPO protein of similar size and concentration to that of normal thyroid tissues. However, the microsomal fractions showed two extra faint bands (about 80 and $90 \mathrm{kDa}$ ). Further analysis of TPO mRNA was conducted by Northern blot. The results showed differences neither in size nor concentration between RNAs from normal thyroid and the patient's tissues (Fig. 1). The above studies indicated that the patient's TPO mRNA and protein were expressed similarly to those of normal thyroid tissues but the patient's TPO protein lacked the enzyme activity.

\section{DNA analysis}

A mutation of the TPO gene was first suspected as a reason for the loss of activity of the patient's TPO protein. Therefore, the nucleotide sequence of the TPO mRNA was analysed by RT-PCR using the total cellular RNA isolated from surrounding thyroid tissue. Sequencing of the TPO mRNA revealed five mutations of TPO mRNA with varying frequencies (Table 2). To confirm these mutations, PCR products derived from genomic DNA prepared from surrounding thyroid tissue and PCR primers specific for the exons were sequenced. The results showed a G808A missense mutation (exon 7) and C insertion at position 2505-2511 (exon 14) at frequencies of $3 / 5$ and $3 / 5$ respectively (Table 2 ). Further sequencing of ten independent clones of RT-PCR products using primers F0519 and R3026 (Table 1) revealed that each clone had only one mutation, either in exon 7 or in exon 14.

Nucleotide sequencing of the patient's TPO mRNA and genomic DNA revealed that the TPO gene mutated at positions 808 (exon 7) and 2505-2511 (exon 14) and that these mutations were heterozygous, one presumably being derived from the patient's mother and the other from her father.

The mother's genomic DNA prepared from peripheral blood mononuclear cells was analysed for the two mutations of the TPO gene. Sequencing of PCR products of exons 7 and 14 showed only the mutation in exon 7 , at a frequency of $2 / 5$. It thus was confirmed that one of the

Table 2 TPO mutations in the patient. Nucleotide sequencing was carried out using RT-PCR products of total cellular RNA purified from the patient's thyroid tissue. Four mutations obtained in RT-PCR products were confirmed by sequencing of genomic DNA PCR product. At least five independent subclones of PCR products were sequenced and the number of subclones that had mutations in their sequence is shown as a frequency

\begin{tabular}{|c|c|c|c|c|c|}
\hline \multirow[b]{3}{*}{ Exon } & \multirow[b]{2}{*}{ Position* } & \multirow[b]{2}{*}{ Nucleotide change } & \multirow[b]{2}{*}{ Nature of mutation } & \multicolumn{2}{|c|}{ Frequency } \\
\hline & & & & mRNA & Genomic DNA \\
\hline & & & & & \\
\hline 1 & $84-86$ & GGT deletion & (5'-noncoding) & $2 / 5$ & $0 / 5$ \\
\hline 7 & 808 & $\mathrm{G} \rightarrow \mathrm{A}$ & Asp $\rightarrow$ Asn & $5 / 5$ & $3 / 5$ \\
\hline 14 & $2505-2511$ & $\mathrm{C}$ insertiont & Frameshift & $5 / 10$ & $3 / 5$ \\
\hline
\end{tabular}

*Numbering is according to Kimura et al. (1989).

†The mutations were described previously (Bikker et al. 1995, 1997).

$\ddagger$ Not tested. 
a

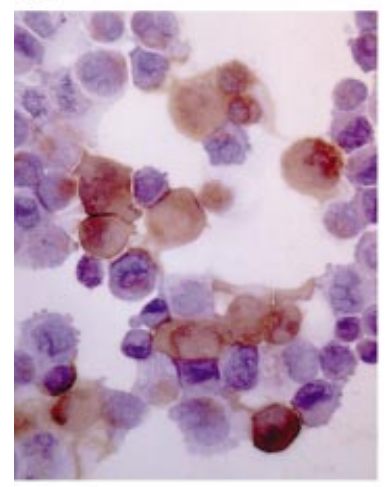

\section{c}

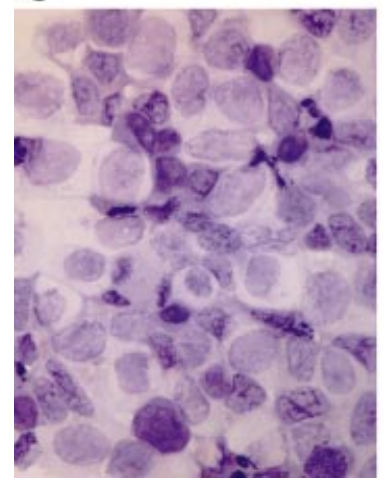

b

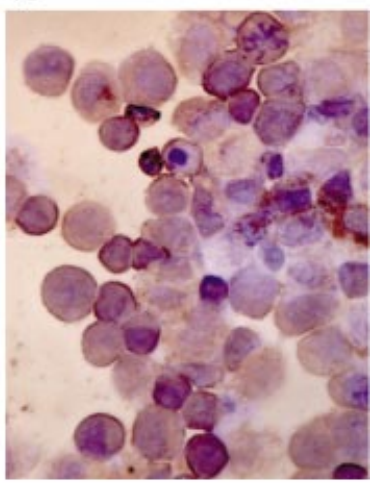

d

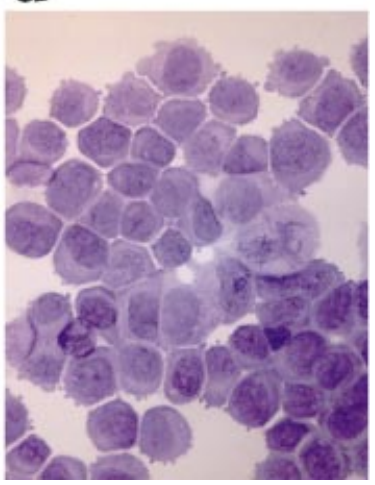

Figure 2 Antibody staining of CHO-K1 cells transfected with mRNAs. For anti-human TPO antibody staining, cells incubated for $24 \mathrm{~h}$ were suspended in $3 \%$ FCS-PBS at $2 \times 10^{6}$ cells $/ \mathrm{ml}$. Cell suspension $(100 \mu \mathrm{l})$ was cytospinned on a slide glass and fixed with acetone-PBS-formalin solution. Cells were stained by an immunoperoxidase streptoavidin-biotin complex method using a Histofine SAB-PO (M) kit (Nichirei). All figures show anti-human TPO antibody stainings: (a) CHO-K1 cells transfected with hTPO-1 mRNA; (b) CHO-K1 cells transfected with G808A mRNA; (c) CHO-K1 cells transfected with pSFV-1 mRNA; (d) CHO-K1 cells transfected without mRNA. Positive staining percentages were (a) $71 \%$, (b) $65 \%$, (c) $2 \%$ and (d) $0 \%$. two mutations in the patient's TPO gene (exon 7) was derived from her mother. However, we could not analyse the TPO gene of the patient's father, as he was unwilling. The $C$ insertion at position 2505-2511 (exon 14) has already been reported as a mutation of the human TPO gene that results in TIOD (Bikker et al. 1995, 1997).

\section{G808A mutation leads to the loss of TPO activity}

The missense mutation G808A in exon 7 of the patient's TPO gene resulted in an Asp240Asn substitution of the TPO protein. To determine whether this amino acid substitution leads to the loss of TPO activity, mRNAs, hTPO-1, G808A and pSFV-1 were transfected to CHO-K1 cells. After 24-h or 34-h incubation, cells transfected with mRNA were analysed for their TPO activity and TPO protein expression. As shown in Fig. 2 and Table 3, cells transfected with G808A mRNA showed no TPO activity although TPO protein was expressed. On the other hand, cells transfected with hTPO-1 mRNA exhibited both TPO activity and protein. Western blot analysis, further, supported TPO protein expression both in cells transfected with G808A and hTPO-1 mRNAs (Fig. 3).

G808A-mutated mRNA expressed TPO protein but lacked TPO activity.

Comparison of amino acid sequence neighbouring the exon 7 mutation between various peroxidases

The amino acid sequence neighbouring the mutation was compared with those of various peroxidases. As shown in Fig. 4, Asp238, His239 and Asp240 of human TPO are well conserved among all known TPO amino acid sequences, including pig, mouse and rat, and also in human eosinophil peroxidase (EPO), bovine lactoperoxidase (LPO), and human and mouse myeloperoxidases (MPO). Recently, De Gioia et al. (1996) have reported that after constructing their three-dimensional models

Table 3 G808A mutation abrogates TPO acitivity. CHO-K1 cells were transfected with mRNA by electroporation. After 34-h incubation, they were subjected to guaiacol assay and anti-TPO antibody staining. About 200 cells stained with antibody were counted

\begin{tabular}{|c|c|c|c|c|}
\hline & \multicolumn{2}{|l|}{ Experiment 1} & \multicolumn{2}{|l|}{ Experiment 2} \\
\hline & $\begin{array}{l}\text { Guaiacol assay } \\
(\mathrm{mU} / \mathrm{mg})\end{array}$ & $\begin{array}{l}\text { Anti-TPO antibody } \\
\text { staining (\%) }\end{array}$ & $\begin{array}{l}\text { Guaiacol assay } \\
(\mathrm{mU} / \mathrm{mg})\end{array}$ & $\begin{array}{l}\text { Anti-TPO antibody } \\
\text { staining (\%) }\end{array}$ \\
\hline \multicolumn{5}{|c|}{$\begin{array}{l}\text { Transfected } \\
\text { mRNA }\end{array}$} \\
\hline hTPO-1 & $6 \cdot 2$ & 46 & 17 & 50 \\
\hline G808A & ND & 50 & ND & 49 \\
\hline pSFV-1 & ND & 2 & ND & 1 \\
\hline - & ND & 1 & ND & 1 \\
\hline
\end{tabular}

$\mathrm{ND}$, not detectable.

$\mathrm{mU} / \mathrm{mg}$, munits/mg microsomal protein. 


\section{kDa}

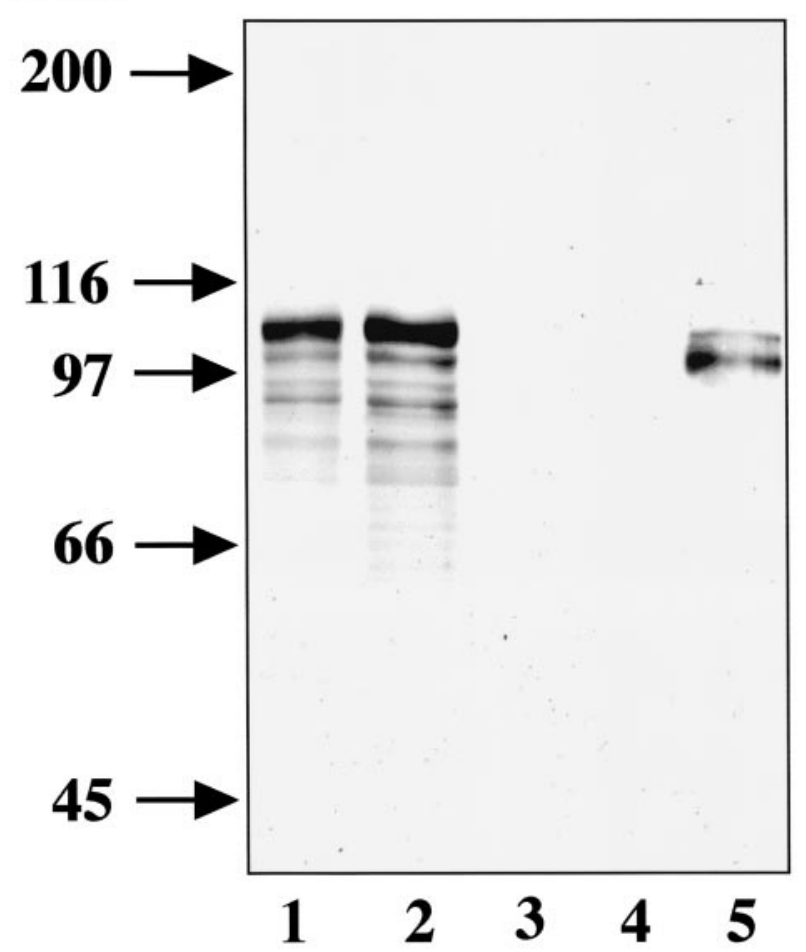

Figure 3 Western blot analysis of $\mathrm{CHO}-\mathrm{K} 1$ cells transfected with mRNAs. CHO-K1 cells incubated for $24 \mathrm{~h}$ were lysed with SDS-PAGE sample buffer $\left(2 \times 10^{6}\right.$ cells $\left./ 100 \mu \mathrm{l}\right)$ and boiled for $5 \mathrm{~min}$. After centrifugation at $10000 \mathrm{~g}$ for $15 \mathrm{~min}, 0.5 \mu \mathrm{l}$ of the resulting sample was separated through $8 \%$ SDS-PAGE and transferred to Immobilon-P (Millipore Corporation). The membrane was incubated with polyclonal rabbit anti-human TPO antibody and then reacted with goat anti-rabbit IgG antibody conjugated with alkaline phosphatase (Promega Corporation): lane 1, CHO-K1 cells transfected with hTPO-1 mRNA; lane 2, CHO-K1 cells transfected with G808A mRNA; lane 3, CHO-K1 cells transfected with pSFV-1 mRNA; lane 4, CHO-K1 cells transfected without mRNA; lane 5, recombinant human TPO (100 ng) (Hata et al. 1989).

from structurally conserved regions identified by the multisequence alignment program, His226 of human LPO, His221 of human EPO and His261 of human MPO are more likely to act as distal His which is linked to the iron centre of the heme. If so, His 239 of human TPO may be distal His, although Kimura \& Ikeda-Saito (1988) suggested that in human TPO the distal His may be located in either exon 9 or 10. Furthermore, the proximal His of human TPO may be His494 in exon 9 (Zeng \& Fenna 1992, Bikker et al. 1997) instead of the prediction of Kimura \& Ikeda-Saito (1988) that the proximal His is located in exon 8. If His239 of human TPO is distal His, the Asp240Asn substitution of the patient's TPO protein would seriously interfere with TPO activity, because
Patient TPO

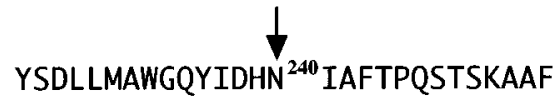

Human TPO

Pig TPO

Mouse TPO

Rat TPO

Human EPO

Bovine LPO

Human MPO

Mouse MPO

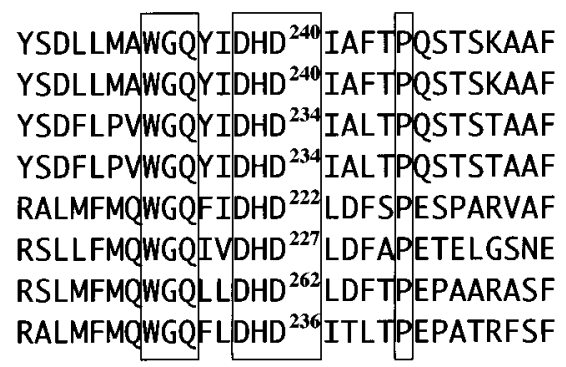

Figure 4 Comparison of the amino acid sequence neighbouring the mutation in exon 7 between various peroxidases. Conserved amino acids are enclosed. The amino acid sequence was adopted from the following references: human TPO, Kimura et al. (1987), pig TPO, Magnusson et al. (1987), mouse TPO, Kotani et al. (1993), rat TPO, Derwahl et al. (1989), human EPO, Ten et al. (1989), bovine LPO, Dull et al. (1990), human MPO, Morishita et al. (1987), mouse MPO, Venturelli et al. (1989). Abbreviations for the amino acid residues are as follows: A, Ala; D, Asp; E, Glu; F, Phe; G, Gly; H, His; I, Ile; K, Lys; L, Leu; M, Met; N, Asn; P, Pro; Q, Gln; R, Arg; S, Ser; T, Thr; V, Val; W, Trp; Y, Tyr.

Asp and Asn are acidic and polar neutral amino acids respectively.

\section{Conclusion}

Two mutations of the TPO gene that resulted in a complete loss of TPO enzyme activity were demonstrated in our patient and it was considered that these mutations were heterozygous, with one derived from the patient's mother and the other from her father.

\section{Acknowledgements}

The authors are grateful to Drs I Yamazaki (The Emeritus Professor, Research Institute of Electronics Science, Hokkaido University) and S Kimura (Laboratory of Molecular Carcinogenesis and Laboratory of Metabolism, National Institutes of Health) for reading the manuscript and valuable discussion. This work was supported in part by a grant from the Clinical Pathology Foundation of Japan.

\section{References}

Abramowicz MJ, Targovnik HM, Varela V, Cochaux P, Krawiec L, Pisarev MA, Propato FVE, Juvenal G, Chester HA \& Vassart G 1992 Identification of a mutation in the coding sequence of the human thyroid peroxidase gene causing congenital goiter. Journal of Clinical Investigation 90 1200-1204. 
Bikker H, den Hartog MT, Baas F, Gons MH, Vulsma T \& de Vijlder JJM 1994 A 20 basepair duplication in the human thyroid peroxidase gene results in a total iodide organification defect and congenital hypothyroidism. Journal of Clinical Endocrinology and Metabolism 79 248-252.

Bikker H, Vulsma T, Baas F \& de Vijlder JJM 1995 Identification of five novel inactivating mutations in the human thyroid peroxidase gene by denaturing gradient gel electrophoresis. Human Mutation 6 9-16.

Bikker H, Waelkens JJJ, Bravenboer B \& de Vijlder JJM 1996 Congenital hypothyroidism caused by a premature termination signal in exon 10 of the human thyroid peroxidase gene. Journal of Clinical Endocrinology and Metabolism 81 2076-2079.

Bikker H, Baas F \& de Vijlder JJM 1997 Molecular analysis of mutated thyroid peroxidase detected in patients with total iodide organification defects. Journal of Clinical Endocrinology and Metabolism 82 649-653.

Bradford MM 1976 A rapid and sensitive method for the quantitation of microgram quantities of protein utilizing the principle of protein-dye binding. Analytical Biochemistry 72 248-254.

De Gioia L, Ghibaudi EM, Laurenti E, Salmona M \& Ferrari RP 1996 A theoretical three dimensional model for lactoperoxidase and eosinophil peroxidase, built on the scaffold of the myeloperoxidase X-ray structure. Journal of Biological Inorganic Chemistry 1 476-485.

Derwahl M, Seto P \& Rapoport B 1989 Complete nucleotide sequence of the cDNA for thyroid peroxidase in FRTL5 rat thyroid cells. Nucleic Acids Research 178380.

Dull TJ, Uyeda C, Strosberg AD, Nedwin G \& Seilhamer JJ 1990 Molecular cloning of cDNAs encoding bovine and human lactoperoxidase. DNA Cell Biology 9 499-509.

Endo Y, Onogi S, Umeki K, Yamamoto I, Kotani T, Ohtaki S \& Fujita T 1995 Regional localization of the gene for thyroid peroxidase to human chromosome $2 \mathrm{p} 25$ and mouse chromosome 12C. Genomics 25 760-761.

Hata J, Yamashita S, Yagihashi S, Kato H, Kabeno S, Hirai K, Kuma K, Kimura S, Umeki K, Kotani T \& Ohtaki S 1989 Stable high level expression of human thyroid peroxidase in cultured Chinese hamster ovary cells. Biochemical and Biophysical Research Communications 164 1268-1273.

Kimura S \& Ikeda-Saito M 1988 Human myeloperoxidase and thyroid peroxidase, two enzymes with separate and distinct physiological functions, are evolutionarily related members of the same gene family. Proteins 3 113-120.

Kimura S, Kotani T, McBride OW, Umeki K, Hirai K, Nakayama T \& Ohtaki S 1987 Human thyroid peroxidase: complete cDNA and protein sequence, chromosome mapping, and identification of two alternately spliced mRNAs. Proceedings of the National Academy of Sciences of the USA 84 5555-5559.

Kimura S, Hong Y-S, Kotani T, Ohtaki S \& Kikkawa F 1989 Structure of the human thyroid peroxidase gene: comparison and relationship to the human myeloperoxidase gene. Biochemistry $\mathbf{2 8}$ 4481-4489.

Kotani T, Umeki K, Matsunaga S, Kato E \& Ohtaki S 1986a Detection of autoantibodies to thyroid peroxidase in autoimmune thyroid diseases by micro-ELISA and immunoblotting. Journal of Clinical Endocrinology and Metabolism 62 928-933.

Kotani T, Umeki K \& Ohtaki S 1986 b A murine monoclonal antibody derived from the immunization of human thyroglobulin reacts equally with L-thyroxine and reverse triiodo-L-thyronine and has a unique idiotype. Endocrinologia Japonica 33 629-636.
Kotani T, Umeki K, Yamamoto I, Takeuchi M, Takechi S, Nakayama T \& Ohtaki S 1993 Nucleotide sequence of the cDNA encoding mouse thyroid peroxidase. Gene 123 289-290.

Laemmli UK 1970 Cleavage of structural proteins during the assembly of the head of bacteriophage T4. Nature 227 680-685.

Libert F, Ruel J, Ludgate M, Swillens S, Alexander N, Vassart G \& Dinsart C 1987 Thyroperoxidase, an autoantigen with a mosaic structure made of nuclear and mitochondrial gene modules. EMBO Journal 6 4193-4196.

Magnusson RP, Gestautas J, Taurog A \& Rapoport B 1987 Molecular cloning of the structural gene for porcine thyroid peroxidase. Journal of Biological Chemistry 262 13885-13888.

Mangklabruks A, Correa Billerbeck A-E, Wajchenberg B, Knobel M, Cox NJ, DeGroot LJ \& Medeiros-Neto G 1991 Genetic linkage studies of thyroid peroxidase (TPO) gene in families with TPO deficiency. Journal of Clinical Endocrinology and Metabolism 72 471-476.

Morishita K, Kubota N, Asano S, Kaziro Y \& Nagata S 1987 Molecular cloning and characterization of cDNA for human myeloperoxidase. Journal of Biological Chemistry 262 3844-3851.

Nakagawa H, Endo Y \& Ohtaki S 1981 A new protease in hog thyroid lysosomes. I. The presence of a leupeptin sensitive protease in the soluble fraction of thyroid lysosomes. Acta Endocrinologica $\mathbf{9 8}$ 383-389.

Nakagawa H, Kotani T, Ohtaki S, Nakamura M \& Yamazaki I 1985a Purification of thyroid peroxidase by monoclonal antibody-assisted immunoaffinity chromatography. Biochemical and Biophysical Research Communications 127 8-14.

Nakagawa H, Kotani T, Ohtaki S, Kawano J, Aikawa E, Imagawa M, Hashida S \& Ishikawa E 1985b Characterization of a monoclonal antibody to hog thyroid peroxidase and its use for immunohistochemical localization of the peroxidase in the thyroid gland. Journal of Biochemistry 97 1709-1718.

Sambrook J, Fritsch EF \& Maniatis T 1989 Molecular Cloning - A Laboratory Manual. Cold Spring Harbor: Cold Spring Harbor Laboratory.

Seto P, Hirayu H, Magnusson RP, Gestantas J, Portmann L, DeGroot LJ \& Rapoport B 1987 Isolation of a complementary DNA clone for thyroid microsomal antigen. Homology with the gene for thyroid peroxidase. Journal of Clinical Investigation 80 1205-1208.

Taurog A 1986 Hormone synthesis: thyroid iodine metabolism. In Werner's The Thyroid, pp 53-97. Eds S Ingbar \& L Braverman. Philadelphia: Lippincott.

Ten RM, Pease LR, McKean DJ, Bell MP \& Gleich GJ 1989 Molecular cloning of the human eosinophil peroxidase. Evidence for the existence of a peroxidase multigene family. Journal of Experimental Medicine 169 1757-1769.

Venturelli D, Shirsat N, Gemperlein I, Bittenbender S, Hudson S \& Rovera G 1989 Nucleotide sequence of cDNA for murine myeloperoxidase. Nucleic Acids Research 175852.

Zeng J \& Fenna RE 1992 X-ray crystal structure of canine myeloperoxidase at $3 \AA$ resolution. Journal of Molecular Biology 226 185-207.

Received 4 December 1997

Revised manuscript received 17 August 1998 Accepted 22 September 1998 